\title{
Chirbes y la «autorreescritura»: las variantes entre los reportajes publicados en la revista Sobremesa y los textos compilados en Mediterráneos
}

\section{Chirbes and "Self-rewriting": Textual Variants between Articles Published in Sobremesa Magazine and Texts Compiled in Mediterráneos}

\author{
Jacobo Llamas Martínez \\ Universidad de León \\ jllam@unileon.es \\ ORCID iD: https://orcid.org/0000-0001-5883-353X
}

\section{RESUMEN}

El cotejo de las variantes entre los textos de Mediterráneos y los reportajes de la revista Sobremesa de los que parten permite intuir los procedimientos de «autorreescritura» de Chirbes y las sucesivas fases de elaboración de su obra. Además de las transformaciones obligadas por el paso de los textos, ilustrados y con recuadros, de la revista Sobremesa al libro de Mediterráneos, sin ilustraciones ni recuadros, Chirbes depuró la expresión guiándose por los principios de claridad, economía lingüística y decoro. El escritor introdujo cambios en la sintaxis y la puntuación, que hacen más fluida la lectura y la comprensión, y omitió y sustituyó secuencias y voces por otras que trasladan a los textos de Mediterráneos matices más precisos y que ilustran sus convicciones de una forma más personal.

Palabras Clave: Chirbes; reescritura; «autorrescritura»; Mediterráneos; revista Sobremesa; variantes textuales.

\begin{abstract}
A comparison of the textual variants between Chirbes's texts in Mediterráneos and his articles in Sobremesa magazine on which these texts are based allows for an understanding of Chirbes's process of "self-rewriting" and the successive stages of elaboration of his work. In addition to making the changes required to transfer the Sobremesa pieces, illustrated and featuring pull-out quotes, to the book Mediterráneos, without illustrations or pull-out quotes, Chirbes improved his use of language according to the principles of clarity, linguistic brevity and decorum. The writer introduced changes in syntax and punctuation that result in smoother reading and comprehension, and omitted and substituted phrases and words for others that bring more precise nuances to the texts of Mediterráneos and illustrate his convictions in a more personal way.
\end{abstract}

Key words: Chirbes; Rewriting; "self-rewriting"; Mediterráneos; Sobremesa Magazine; Textual variants. 
Rafael Chirbes formó parte de la redacción de Sobremesa, revista de gastronomía y vinos, desde la edición del primer número en febrero de 1984 y hasta $2007^{1}$. En ese tiempo ejerció como redactor, redactor jefe, director, asesor de dirección o colaborador de la publicación, para la que escribió numerosos artículos sobre crítica gastronómica y reportajes de viajes. Chirbes (1997a y 2008) compiló doce de estos últimos en Mediterráneos (Debate, 1997, reeditado por Anagrama en 2008) y cuarenta y dos en El viajero sedentario (Chirbes 2004) ${ }^{2}$. El cambio de formato de los textos supuso la supresión de despieces, fotos, pies de foto, ladillos, e implicó, como reconoció el autor, modificaciones de distinta índole; algunos textos sufrieron leves modificaciones (corrección de erratas, cambios de puntuación, adición o supresión de expresiones), otros fueron sometidos a modificaciones de mayor calado (refundición y omisión de párrafos enteros), que confirman el rigor con el que Chirbes revisaba y escribía sus obras: «Soy de los que para ajustar una frase coherente necesito escribirla diez o doce veces (qué difícil es el viaje de la cabeza al papel, lo dijo Kafka), borrar, romper, reintentar: o sea, que estos cuadernitos expresan algo más parecido al vagido de un niño que a lo que entendemos por un texto» (Chirbes 2009, 14). El narrador y personaje de En la lucha final del que no se conoce el nombre manifiesta: «He corregido adjetivos, construcciones sintácticas y signos de puntuación. Pero las palabras parecían girar en el aire y luego regresaban y me golpeaban en la cabeza como boomerangs» (Chirbes 1991a, 181).

Los comentarios anteriores podrían aplicarse al modus operandi de Chirbes al revisar la mayor parte de los reportajes de la revista Sobremesa compilados en Mediterráneos y El viajero sedentario, pero también a las sucesivas fases de redacción y corrección de sus novelas antes de considerarlas aptas para su edición, como ratifica en distintos lugares Jorge Herralde, director de Anagrama y editor de la mayor parte de las obras publicadas por el escritor (véase, por ejemplo, Herralde 2006, 84).

Esta exigencia de Chirbes responde, por una parte, a su creencia en el «trabajo bien hecho», por lo que deseaba que en sus novelas se reconociesen los esfuerzos compositivos como escritor con independencia de que agradasen al público y a la crítica ${ }^{3}$; por otra, a los postulados de la crítica

${ }^{1}$ Meses después escribiría y publicaría el último de sus textos (sobre Aviñón) para la publicación. Val $(2014-2015,288)$ explica que en 1982 Chirbes «llega a Madrid y pasa algún tiempo en La Gaceta Ilustrada», antes de iniciar su relación con Vinoselección, un club de vinos para el que creó la revista Sobremesa.

2 Los textos de Mediterráneos (Madrid, Debate, Chirbes 1997a) y los de Mediterráneos (Madrid, Anagrama, Chirbes 2008) presentan alteraciones exclusivamente en la paginación.

${ }^{3}$ Gran Sol, de Ignacio Aldecoa, ejemplificó para Chirbes $(2010,165)$ la idea del «trabajo bien hecho», el de los pescadores en el caladero y el del novelista que describe y relata esas labores con exactitud: «[Gran Sol] es una muestra canónica de esa forma de en- 
estructuralista, que entiende que los elementos compositivos de un texto (desde el lenguaje hasta los blancos) trasladan sesgos ideológicos, relaciones de poder y dominación. Para no incurrir en ellos, al menos de manera consciente, Chirbes reflexionaba escrupulosamente sobre cada decisión que tomaba en su obra:

No hay distinción entre fondo y forma, y por eso no se puede resumir; [la novela] dice lo que dice [...] Los buenos críticos descubren todos esos aspectos de los que el propio novelista no es consciente mientras escribe. Todos sus elementos son elementos de significado [...] Un libro es lo que es: un conjunto de palabras. Y lo que esas palabras ordenadas de determinada manera cuentan es, a la vez, su fondo y su forma. El lenguaje - cargado de una densidad que es a la vez tiempo y sentido- es su andamiaje constructivo, pero también su ritmo, su respiración, su tono; y es en los pliegues del lenguaje [...] donde se refugia el sentido (López de Abiada 2011, 20 y 34) $)^{4}$.

Como se verá, la reescritura en Mediterráneos de los textos aparecidos por primera vez en la revista Sobremesa ilustra parte de los aspectos previos y revelan un usus scribendi y unas convicciones muy semejantes a los de las novelas de Chirbes.

\section{FUENTES, INTERTEXTUALIDAD, REESCRITURA Y «AUTORRESCRITURA»}

Los estudios sobre fuentes y reescritura han proliferado desde la Antigüedad clásica. En tiempos recientes — «desde que en 1967 Julia Kristeva introdujo el término y el concepto de "intertextualidad"», que engloba los de fuentes y reescritura-, el concepto «se ha asentado como característica ineludible de todo texto verbal a la vez que como fenómeno activo que en los textos literarios la crítica debe atender, describir, analizar y valorar» (Martínez Fernández 2001, 9 y 37). En el ámbito lingüístico y filológico, los análisis «intertextuales» emplean disciplinas, históricas, teóricas, comparadas, para aproximarse a diversas épocas, géneros, temáticas, motivos, obras, con objetivos ecdóticos, estilísticos, sociales, ideológicos ${ }^{5}$. Como manifestó el propio Chirbes $(2002,80-81)$ cuando se planteó

tender la narrativa, tanto por el tema - la vida cotidiana de los pescadores de altura del Cantábrico- como por la precisión del utillaje del que el novelista se vale para crear un tupido universo literario».

${ }^{4}$ Al comentar algunas de las impresiones que le mereció la lectura de La Celestina, Chirbes $(2010,53)$ insistió: «La palabra no sirve para conocer, sino que da poder, domina y esconde».

${ }^{5}$ La noción acuñada por Kristeva fue matizada por autores posteriores: «Lo que hoy llamamos "intertextualidad", en cualquiera de sus concepciones, global o de carácter restrictivo, es un concepto moderno, aunque su práctica es tan antigua como la propia literatura. El concepto moderno $[\ldots]$ no puede desligarse $[\ldots]$ de otros acercamientos históricos a la literatura 
la «intertextualidad» de la novela, el panorama resulta amplísimo. Chirbes (2002, 67 y 2010, 27) evidenció la «intertextualidad» de sus novelas, deudoras tanto de «Marx y Lucrecio» como de «Balzac y Proust», y explicitó varios casos. El narrador poco fidedigno de la novela El buen soldado, escrita por Ford Madox Ford, sirvió a Chirbes de inspiración para el narrador y personaje de Carlos Císcar en Los disparos del cazador; Torquemada, de Galdós, y Vautrin, de Balzac, para el mismo Carlos Císcar y para el personaje de Rubén de Bertomeu en Crematorio ${ }^{6}$. De modo menos categórico, Chirbes $(2008,11-16)$ apuntó la «intertextualidad» entre los textos de Mediterráneos y el libro de Fernand Braudel, El Mediterráneo y el mundo mediterráneo en la época de Felipe II: «Leer y entender mejor a Braudel ha ido ayudándome a entender mi propio mar» (Chirbes 2008, 14).

Este artículo se centra, sin embargo, en un aspecto más restringido de la noción de «intertextualidad», el de la «intratextualidad» aducido por Martínez Fernández $(2001,151)$ : «hablo de intratextualidad cuando el proceso intertextual opera sobre textos del mismo autor». Y más concretamente en una de las modalidades que la integran: la de reescritura, que puede denominarse «autoreescritura ["autorreescritura" en este trabajo]», como hizo Vitse (1998, 6-7) para referirse a las diferentes versiones de La vida es sueño y La dama duende compuestas por Calderón, puesto que en este artículo se estudian las modificaciones introducidas por Rafael Chirbes en textos de su autoría ${ }^{7}$.

La «autorreescritura», como la «intertextualidad», es un fenómeno común a los autores de las diferentes lenguas y períodos, y forma parte del oficio de cualquier escritor ${ }^{8}$. Chirbes también dejó constancia de varios casos de «auto-

basados en la relación entre textos, desde el viejo concepto de influencia a la huella derridiana» (Martínez Fernández 2001, 197). De la intertextualidad, de sus ámbitos y posibilidades de estudio también se ocupan Plett (1993), González Álvarez (2003) o Gómez Alonso (2017), pero la bibliografía es muy extensa. Para la tradición francesa, una de las más fecundas desde los trabajos de Genette (1982), léanse la compilación de Aron (1987) y Ricardou (1989).

${ }^{6} \mathrm{El}$ escritor expuso otro caso de influencia que escapa al de la «intertextualidad» entendida como relación de un texto propiamente con otro u otros: «[de la visión pictórica de Bacon] surgió uno de los personajes más siniestros de mi libro La caída de Madrid, un torturador asustado por los cambios que en su vida pueden producirse a la muerte de Franco» (Chirbes 2002, 59). Chirbes (2009a) reconoció hacia el final de esa intervención que tuvo una obra modelo en mente para cada novela que escribió. Orsini-Saillet (2007, 67-68, nota 141), Luengo (2009), Maggi (2015), Senabre (2015) y Valls (2014-2015 y 2016) exponen otros casos de intertextualidad en las novelas de Chirbes.

7 Martínez Fernández (2001, 81 y 161-162) utiliza genéricamente el término reescritura («reescribir supone remover los textos propios»), que considera que se produce «cuando la escritura previa ha sufrido una transformación notable»; Sáez (2013, 161-162) entiende que la reescritura se da «cuando es evidente que el escritor - $u$ otra persona- actúa según una tentativa consciente de reutilizar - de la forma que sea- la parte o el todo de un texto original».

${ }^{8}$ Una síntesis de este tipo trabajos de reescritura y «autorreescritura», con especial interés para la edición crítica de textos novelescos españoles, en Arcotxa-Scarcia, LluchPrats y Olaziregi (2010), Vauthier y Gamba Corradine (2012) e Iglesias Feijoo (2013). 
rreescritura macroestructural», aquella que afecta al conjunto de la obra. Aprovechando la reedición de La buena letra (1992) en el año 2000, el autor decidió suprimir el capítulo final de la novela que reunía a Ana con Isabel, quien había sido su rival; las razones que esgrime para ello son tan contundentes y sutiles que amilanan cualquier intento de análisis:

Cuando escribí el libro, me pareció que, por respeto al lector, al final de la novela debía devolverlo al presente narrativo del que lo había hecho partir, y, por ello, puse [...] ese capítulo [...] en el que las dos cuñadas -Ana e Isabel- volvían a encontrarse tantos años después. [...] Pasado el tiempo me pareció que el libro no necesitaba de ninguna circularidad consoladora [...] El paso de una nueva década ha venido a cerciorarme de que no es misión del tiempo corregir injusticias, sino más bien hacerlas más profundas. Por eso, quiero librar al lector de la falacia de esa esperanza y dejarlo compartiendo con la protagonista Ana su propia rebeldía y desesperación (Chirbes 2000, 7-8).

Chirbes $(2010,288)$ mencionó otro caso de «autoreescritura macroestructural» en Crematorio, novela que «perdió un par de capítulos que disonaban o no añadían nada nuevo» antes de que pudiera leerla el editor Jorge Herralde ${ }^{9}$.

Como se avanzó al comienzo, Chirbes $(2008,159)$ dejó claro el caso de «autorreescritura» de los textos incluidos en Mediterráneos: «algunos aparecieron en su día tal y como pueden leerse aquí; otros, sin embargo, han sufrido cambios sustanciales». Pero de todas estas «autorreescrituras» se pueden extraer conclusiones de interés para conocer el «taller del escritor»: las convicciones, las preferencias y los hábitos de Chirbes como autor ${ }^{10}$.

9 Asimismo, en la obra de Chirbes se localizan bastantes lugares de lo que RodríguezGallego $(2016,89)$ denominó «microrreescritura» a la hora de estudiar la manera en que Calderón reescribió o reutilizó «materiales propios [en distintos] fragmentos [de su obra] [...] desde conjuntos de unos pocos versos hasta cuadros o macrosecuencias, pasando por diferentes motivos». Desde esta perspectiva se podrían examinar, por ejemplo, las reflexiones de Chirbes $(2002,69-90$ y 2010, 11-37) en torno a la naturaleza de la novela y del lenguaje o los motivos del espejo, la memoria y el «boomerang», a los que el escritor aludió en diferentes ensayos y novelas, y cuya noción ayuda a entender la concepción que Chirbes tuvo de los procesos históricos.

${ }^{10}$ El término «taller» es muy apropiado para referirse a la manera en que Chirbes (2010, 293-294) concibió la creación literaria; este comparó el oficio de escritor con el de «carpinteros, cerrajeros, estucadores, albañiles [...] También mi libro, como las paredes, las puertas y los grifos, es sólo un fruto del trabajo». Una carpintería es el eje del argumento de En la orilla; la cubierta de Por cuenta propia (Chirbes, 2010) reproduce la pintura «Raboteurs de parquet», de Gustave Caillebotte. Las reminiscencias ideológicas de todo ello son diáfanas: Chirbes comparó su trabajo de escritor con el de los obreros, a quienes él mismo se equiparó por sus orígenes humildes; esto distancia a Chirbes de una parte de escritores más o menos contemporáneos a él (los nacidos en la década de los cuarenta), que procedieron de las clases acomodadas, gozaron de acceso a la formación y la cultura, y acostumbraron a escribir sobre los de su misma condición. Valls (2014-2015) señala las implicaciones con- 


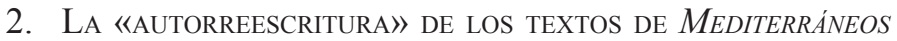

Chirbes reunió en Mediterráneos (Chirbes 1997a y Chirbes 2008) doce reportajes publicados en la revista Sobremesa, entre octubre de 1986 y febrero de 1997, sobre sus visitas a Creta, Valencia, Estambul, Lyon, Génova, Venecia, Alejandría, Gabes, Dénia, El Cairo, Levante y Roma. A estos reportajes se añaden dos textos escritos para la compilación: el primero a modo de prólogo, «Ecos y espejos» (Chirbes 2008, 9-16), fue firmado en mayo de 1997; en el segundo, «Postdata», Chirbes $(2008,159)$ declaró que «todos estos escritos excepto el dedicado al Mediterráneo- fueron naciendo como artículos en la revista Sobremesa», y que los textos incluidos en Mediterráneos sufrieron cambios de «ritmo» y de «tono» con respecto a los editados previamente en Sobremesa.

Como se explica en «Ecos y espejos», los reportajes compilados por Chirbes ofrecen la impresión que le causan distintas localidades mediterráneas; todas ellas le traen recuerdos («ecos») de sus orígenes valencianos («mediterráneos», pues) y le permiten constatar que comparten (reflejan como un «espejo») hábitat, costumbres, arquitecturas u olores: «Me llegó [de la lectura de Braudel] que hay algo en nosotros [los mediterráneos] [que] se repetía en Estambul, en Génova, en las laderas de Creta [...] en las callejuelas de las medinas de Túnez o de Fez [...] en Marruecos [...] en un laberinto de olores» (Chirbes 2008, 14-15) ${ }^{11}$.

El orden de los textos que integran Mediterráneos no resulta tan sencillo de dirimir. Chirbes $(2008,159)$ indicó que modificó algunos de los reportajes

ceptuales del cuadro de Otto Dix, conocido como «Tríptico de la gran ciudad» o «Metrópolis», que figura en la cubierta de En la lucha final, y las de «Punto de mira II», de Juan Genovés, en la de La larga marcha.

${ }^{11}$ Chirbes $(2008,16)$ manifestó: «Con el paso del tiempo, he llegado a muchos lugares y he tenido la impresión de que todos los viajes me servían para leer mejor el lugar originario. De eso trata este libro. De los ecos y espejos cuyas imágenes multiplicadoras han acabado por devolverme siempre a mí mismo». (En el Silencio de la escritura, libro citado y leído por Chirbes, Lledó 1992, 46-50, se ocupa de la noción «especular» de la escritura). Mediterráneos comienza con una cita, traducida al español, del prefacio de El Mediterráneo y el mundo mediterráneo: «Le lecteur qui voudra aborder ce libre comme je le souhaite, fera donc bien d'apporter ses propres souvenirs, ses visions de la mer Intérieure et, à son tour, d'en colorer mon texte, de m'aider à recréer cette vaste présence» (Braudel 1966, 13). Mora (1997) comentó al reseñar Mediterráneos: «Después de pasar 40 años "huyendo de ser valenciano", y alentado por el espíritu de El Mediterráneo y el mundo mediterráneo, del historiador francés Fernand Braudel, Chirbes relee su historia personal "ordenando esos colores y paisajes cotidianos que a veces nos parecen vulgares pero son piezas de una gramática distinta"». Un análisis de estas cuestiones en Fernández Martínez (2021) y García Prats (2013), quien resalta en El viajero sedentario (Chirbes, 2004) cómo «el objeto del viaje de Chirbes no reside en la ciudad, sino en el propio sujeto», en un personaje («el viajero») que se desplaza por el espacio y traslada sus experiencias (García Prats 2013, 139). 
originales de la revista Sobremesa para ajustarlos al ritmo y al tono del libro, y puntualizó: «Creo que, así reunidos y corregidos, dicen algo distinto de lo que decían un mes tras otro». No obstante, la distribución de los textos, con excepción de los de «Ecos y espejos» y «Postdata», no parece responder a un criterio cronológico ni temático claro.

Se puede entender que el primero de los textos de Mediterráneos se dedique a la ciudad de Creta, centro de la civilización minoica, la más antigua de la que se tiene constancia en Europa, y que el segundo se consagre a Valencia, primera de las ciudades que debió de conocer Chirbes, nacido en Tavernes de la Valldigna (Valencia); pero el resto de textos se alternan sin una coherencia clara $^{12}$. Se podría especular con que el dedicado a la ciudad de Roma, con un final conclusivo sería un buen término para el libro («Digamos que, en Roma, al igual que los hombres, también los dioses -a su debido tiempo- van regresando al polvo de los sueños que los engendraron», Chirbes 2008, 158) ${ }^{13}$; pero, como constata Val $(2015,292)$, otras piezas tienen «una conclusión casi editorializante: "El Mediterráneo se ha convertido en un mar agonizante que ya no es corazón de casi nada"». Asimismo, el párrafo final de «La puerta del mar», que menciona a los franceses sin rumbo que se instalan en Estambul, establece una cierta transición con «En el camino», donde se alude a la ciudad de Lyon, de la que se subraya el que haya sido históricamente y en el presente un lugar de paso dentro de Europa, fronterizo, como la propia Estambul. El salto de Lyon a Génova («Paseo por la vieja Génova») y el de Génova a Venecia («El naufragio interior») podría ampararse en la proximidad geográfica de las tres ciudades; el texto sobre Benidorm, (Alicante, «Desde el Estado del bienestar»), situado inmediatamente antes del de la ciudad de Roma, devolvería al «viajero» Chirbes a sus orígenes valencianos. Con todo, este itinerario se rompe abruptamente al trasladarse el «viajero» desde Venecia a Alejandría o desde Dénia a El Cairo, de manera que el orden de los textos de Mediterráneos se guía por la variedad y la alternancia de tiempos, lugares y espacios. Además, la panoplia de ideas que surge de esta sucesión de tiempos, lugares y espacios, parece corresponderse con la amalgama de civilizaciones surgidas al amparo del mar Mediterráneo y con el de hombres que vivieron y viven en sus orillas.

12 García Prats $(2013,286)$ comenta el posible simbolismo del texto sobre Creta y de la alusión de Chirbes al hilo del Minotauro: «Ese hilo constituye precisamente una formulación literaria del imaginario cultural de la franja mediterránea, que lo concibe como un contexto simbólico que desempeña la función de proveer al individuo contemporáneo de una memoria común, de una narración compartida». Más detalles en Fernández Martínez (2021).

13 Otras reflexiones sobre el tiempo («Roma siempre activa dolorosamente en el viajero ese virus de la melancolía. [...] Y eso lo enfrenta a la contradicción que existe entre el interminable tiempo de los dioses y el tiempo mezquino de los hombres» Chirbes 2008, 151) conectan con las ideas de Braudel $(1966,21)$, quien distinguió entre «la plus longue dureé» de los fenómenos geológicos y la fugacidad «de la vie des hommes», y retrotraen al lector al comienzo de la obra. 
El tono misceláneo con el que se agrupan los reportajes en Mediterráneos viene reforzado por el uso de la primera persona y de la tercera representada por un «viajero», a la que Chirbes recurrió para titular su libro El viajero sedentario (Chirbes 2004), que compila otros cuarenta y dos textos publicados originalmente en la revista Sobremesa ${ }^{14}$. La figura del viajero, correlato del propio autor y presente en todos los reportajes de Sobremesa, desaparece en parte de los incluidos en Mediterráneos - «Añoranza de alguna parte», «En el camino», «Paseo por la vieja Génova», «Arqueología del humo», «Desde el Estado del bienestar»-, donde Chirbes utilizó la primera persona para transmitir la impresión que le causan los lugares que visita. Los textos de Mediterráneos se presentan así como una sucesión de viajes o capítulos que pautan el ritmo del relato y que remiten a un mismo viajero, que se puede asimilar a un personaje que ejerce como descriptor y narrador -en primera o en tercera persona del singular- de unos hechos que alientan sus reflexiones e introspecciones. Del mismo modo que sucedía en La larga marcha (1996) y La caída de Madrid (2000), Chirbes parece que estaría experimentando con las voces y los narradores al reescribir los reportajes de Sobremesa para Mediterráneos (1997) ${ }^{15}$ :

Tít Desde el Estado del bienestar $M$ : Benidorm en invierno. Desde el Estado del bienestar $S$

Lad I $M:$ om $S$

1 abrí $M$ : abrió $S$

2 me $M:$ le $S$ om $M:$ al viajero $S$

7 dejé $M$ : el viajero dejó $S$ avancé $M$ : avanzó $S$

Tit La puerta del mar $M$ : Estambul $S$

94 el viajero $M:$ los viajeros $S$

${ }^{14}$ En una reseña de El viajero sedentario, Gómez López-Quiñones (2006, 108) destaca que parte de los textos «resultan anacrónicos. Anacronismos conscientemente asumidos que constituyen además parte del encanto y de la compleja estructura espacio-temporal del volumen». García Prats (2013) estudia en detalle la relevancia de la figura del viajero en la narrativa de viajes de Chirbes, a la que «corresponde el resolver tanto las cuestiones relativas al itinerario y al ritmo como a la perspectiva y al tono. [...] Corresponde asimismo a este personaje seleccionar los elementos con los que construye en el texto un paisaje selectivo, que resulta, al cabo de la elaboración literaria, un mapa o trasunto de su propia figura» (García Prats 2013, 109-110). Entre sus fuentes, Braudel (1966) incluyó crónicas de viajes de diferentes épocas, por ejemplo, The Travels of John Sanderson in the Levant (1584-1602) o Voyage du célebre Benjamin de Tudelle autour du monde comencé l'an MCLXXIII, y llegó a comparar la labor de alguno de estos viajeros con la del historiador (Braudel 1966, 26).

15 Orsini-Saillet $(2007,227)$ señala: «La larga marcha et La caída de Madrid sont les deux romans où Rafael Chirbes utilise la forme du narrateur non-personnel et o il a recours des jeux de focalisations variables, ce qui implique, a priori, une forte présence de la voix narrative». Por esa misma época Chirbes comenzó la póstuma Paris-Austerliz (léase Valls 2016, 40). 
102 el viajero-fotógrafo $M$ : el fotógrafo $S$

413-414 Al viajero le $M$ : a los viajeros les $S^{16}$

La combinación de voces otorga a los textos de Mediterráneos un tono narrativo e intimista (próximo al de la novela psicológica) y un ritmo de lectura en capítulos (algunos de estos capítulos se subdividen a su vez en I, II, III...) del que los reportajes de la revista carecen ${ }^{17}$.

Otros cambios de tono y de ritmo se trasladan a la «autorreescritura» de cada uno de los textos de Mediterráneos, en los que se introducen variantes de distinta consideración con respecto a los de Sobremesa. Por ello, la afirmación de Chirbes $(2008,159)$, «algunos aparecieron $[\ldots]$ tal y como pueden leerse aquí; otros [...] han sufrido cambios sustanciales», debe ser matizada, puesto que todos los textos de Mediterráneos procedentes de la revista Sobremesa fueron modificados. Si bien, se puede distinguir entre los que sufrieron una revisión leve y los que experimentaron una transformación más significativa, tanto por la cantidad de cambios como por la naturaleza de esos cambios. Entre los primeros se pueden situar los textos de «Fragmentos de la Edad de Oro [Creta]»; «En el camino [Lyon]»; «El naufragio interior [Venecia]»; «Paseo por la vieja Génova»; «Desde el Estado del bienestar [Levante]» $\mathrm{y}$ 《El tiempo de los dioses [Roma]», donde se advierten cambios en la puntuación y la adición y supresión de ciertas secuencias, que no suponen una transformación sustancial:

${ }^{16}$ La letra $M$ y el número o números de línea hacen referencia a los textos de Mediterráneos en Anagrama, Barcelona, 2008 (Chirbes 2008); la letra $S$ a los de la revista Sobremesa, cuyo número, año, mes y páginas en los que fueron publicados los reportajes se especifica en la bibliografía final (Chirbes 1986, 1991b, 1994a, 1994b, 1995, 1996a, 1996b, 1996c, 1996d, 1997b). La letra $T$, que aparece posteriormente, hace referencia a uno de los reportajes de Sobremesa recuperado en Turia: revista cultura (Chirbes 1997c). Por razones de espacio y de copyright, en este artículo se resalta una pequeña parte de las variantes detectadas entre diez de los doce textos publicados en Mediterráneos $(M)$ con respecto a las versiones de la revista Sobremesa $(S)$, lo ideal sería presentar el aparato de variantes completo; no se ha conseguido cotejar "Las frutas del olvido», firmado en octubre de 1992, ni «El tamaño de las cosas», firmado en febrero de 1994 (Chirbes 2008, 103-109 y 111-122). El cotejo parcial de los textos de El viajero sedentario (Chirbes 2004) procedentes de la revista Sobremesa apunta fenómenos parecidos a los rastreados en los de Mediterráneos, aunque el número de intervenciones, es decir, de secuencias reescritas o «autorreescritas» parece mayor tal como corroboró el propio Chirbes $(2004,371)$ : «Han sufrido cortes, correcciones y ajustes $[\ldots]$...

17 García Prats $(2013,234)$ constata que el viajero de Mediterráneos no traza una visión exhaustiva de las ciudades que recorre, «sino una subjetiva, en ocasiones azarosa», que constituye una especie de «carta de navegación que present[a] al lector algunos fragmentos del contexto urbano». Las palabras de Braudel (1966, 13), evocadas por el mismo Chirbes (2008, 7), referían: «Malhereusement ou hereusement, notre métier n'a pas les admirables souplesses du roman». 
Tít Fragmentos de la Edad de Oro $M$ : Viaje a Creta. Fragmentos de la Edad de Oro $S$

25 Desde el avión, contemplaba el viajero $M$ : Desde la ventanilla del avión, veía el viajero $S$

145-146 uno de los momentos $M$ : uno de esos momentos $S$

174 de cámara; la basílica $M:$ de cámara, un trío, un cuarteto, un soprano que canta un lied de Schubert; la basílica $S$

Tít En el camino $M$ : Breve encuentro con Lyon. En el camino $S$

1-5 En 1856 entró en servicio el túnel de Saint Irenée y se procedió a conectar la línea ferroviaria París-Lyon con la de Lyon-Marsella, para que el trayecto entre la capital francesa y el Mediterráneo se efectuara sin que los pasajeros tuviesen $M:$ En 1856, se concluyó la construcción del túnel de St. Irenée y se procedió a unir las dos líneas del tren París-Lyon y Lyon-Marsella, consiguiendo así que el trayecto entre la capital francesa y el Mediterráneo se efectuase sin necesidad de que los pasajeros tuvieran $S$

46 Blanc $M$ : Blanch $S$

116 elegantes y tristes fachadas $M$ : elegantes fachadas $S$

124-125 de aquel viajero $M:$ del viajero $S$

139-140 Pasé siempre apresurado por Lyon, y en cada nuevo encuentro con la ciudad fui descubriendo $M$ Así, el viajero pasó otras veces -siempre apresurado- por Lyon, y en cada visión de la ciudad, fue descubriendo $S$

238-239 los restaurantes populares $M:$ los estupendos y animados restaurantes populares $S$

Tít Paseo por la vieja Génova $M$ : La resaca de la historia. Génova $S$

47 tejidos que llegaban $M$ : tejidos que, a través de los interminables desiertos y de los remotos océanos, llegaban $S$

112 om $M$ : espléndido $S$

113 om $M$ : bellísima $S$

134 om $M$ : impresionante $S$

139 om $M$ : imponente $S$

Tit El naufragio interior $M T$ : Venecia. El naufragio interior $S$

Lad I $M T:$ om $S$

2 estaba $M T$ : le iba $S$

3 quizá $M$ : quizás $S T$

4 permanecía atento a la $M T$ : estaba atento a su $S$

8 han querido, soportado, y, ahora $M T$ : quisieron al principio, dejó se soportaran $S$

21 tienen un esqueleto de $M T$ : están formados por $S$

23 hermosas $M T$ : bellas $S$

47 de tren $M T$ : del tren $S$

49 Mann. MT : Mann, Azúa (este último, y malgré lui, se cayó de los labios de un matrimonio catalán) $S$

54-55 las páginas de otras $M T:$ otras $S$ 
70-71 El metro de platino iridiado $M T$ : Parodiando el título de la última novela de Pombo su metro de platino iridiado $S$

74-75 estupidez $M T$ : estúpida locura $S$

76-78 si la habitación tendrá vistas al canal como le han prometido en la agencia $M T:$ y se pregunta si tendrá vistas al canal $S$

87 hermoso!», una $M T$ : bonito!». Es una $S$

113-114 Venecia no era todavía un gran supermercado de los sentimientos $M T:$ om $S$

136 del Veronés $M T:$ de Veronés $S$

Tít Desde el Estado del bienestar $M$ : Benidorm en invierno. Desde el Estado del bienestar $S$

27 la izquierda $M$ : su izquierda $S$

171 el fenómeno Benidorm $M$ : este fenómeno llamado Benidorm $S$

172 le han clavado a un concepto romántico y minoritario del viaje implantado por las clases altas de los países anglosajones, que partían en busca de subdesarrollo, exotismo $M$ : cada vez más numerosas que acceden al Estado del bienestar le dan un concepto romántico del turismo implantado por las clases altas de los pueblos sajones, en busca de subdesarrollo, exotismo $S$

215-217 hasta su jubilación un puesto similar en una cafetería de Logroño, Vigo, Rotterdam o Norfolk. $M$ : él mismo un puesto de camarero en un bar de La Rioja, Rotterdam o Norfolk. $S$

Tit El tiempo de los dioses $M$ : Volver a Roma. El tiempo de los dioses $S$

7 Coliseo $M$ : Colosseo $S$

33 un barniz $M$ : un celofán $S$

203 verde pistacho $M:$ om $S$ rojo salmón $M$ : salmón $S$

Pese a que la «autorreescritura» en los textos anteriores no afecta sustancialmente al contenido de los pasajes, los cambios muestran el proceder minucioso y exacto de Chirbes a la hora de escribir y de manejar el lenguaje. Las modificaciones optan por una mayor precisión lingüística en la selección de secuencias y términos: durante las primeras horas del día, un sol de invierno recubre las piedras y las fachadas romanas con «un barniz de miel» («El tiempo de los dioses», Chirbes 2008, 149), no con un «celofán de miel»; el viajero contempla, subido en el avión -y a través de su ventanilla si acaso- la «silueta de Creta», no la ve desde la ventanilla del aeroplano («Fragmentos de la Edad de Oro», Chirbes 2008, 20).

Muchas de estas transformaciones afectan a su vez a la sintaxis y a la puntuación e inciden sobre la fluidez de la oración y el ritmo de lectura de los pasajes, cuestiones que Chirbes tuvo muy en cuenta en sus novelas ${ }^{18}$. Así,

18 Llamas (2017) comenta varios fragmentos de las novelas de Chirbes en los que la puntuación, ligada a la mayor o menor complejidad de los elementos sintácticos, condicio- 
se especifica que el narrador pasa por Lyon «siempre apresurado» («En el camino», Chirbes 2008, 67), mientras que en el texto de la revista Sobreme$s a$ se aclara que cada vez que pasa por la ciudad lo hace siempre con prisa; igualmente, se prescinde del gerundio «consiguiendo» y de expresiones que complican la sintaxis innecesariamente para explicar, de forma mucho más elegante y armónica, cómo la construcción del túnel de Saint Irenée en Lyon facilitó la comunicación por tren entre París y Marsella («En el camino», Chirbes 2008, 63). En aras de esta agilidad lingüística, al reescribir los reportajes de Sobremesa incluidos en Mediterráneos, Chirbes también tendió a suprimir los determinantes demostrativos y a sustituir los posesivos por artículos, más sutiles o evocadores y que facilitan la lectura, puesto que no es necesario pensar en el referente de los mismos («uno de los momentos», «Fragmentos de la Edad de Oro», Chirbes 2008, 24, en lugar de «uno de esos momentos» Chirbes 1996b).

Las variantes anteriores, que abundan entre los textos de la revista Sobremesa y Mediterráneos, muestran la preocupación de Chirbes por la elocutio y ratifican declaraciones aducidas páginas atrás como «soy de los que para ajustar una frase coherente necesito escribirla diez o doce veces» (Chirbes $2009 b, 14)^{19}$.

Otras alteraciones introducidas por Chirbes suponen mejoras sustanciales en el significado y manifiestan de paso parte de sus convicciones. De este modo, el escritor retocó varias secuencias al referirse a las ideas del sociólogo Mario Gaviria: en Chirbes $(2008,143)$ no se alude a «este fenómeno llamado Benidorm», sino a que la ciudad de Benidorm ha devenido en paradigma por antonomasia del turismo y la especulación inmobiliaria en España («el fenómeno Benidorm» ${ }^{20}$, y se prefiere hablar de «clases altas» y no de las personas que acceden al «Estado del bienestar». Con ello se resaltan, entre otros aspectos, las diferencias que existen entre la vida de las élites y la de los trabajadores o asalariados, aunque estos sean cada vez menos conscientes de esa dicotomía. Más adelante, el término «jubilación» reitera ambas ideas en el texto: un camarero, que disfruta del retiro en Benidorm, es atendido por otros camareros

na el ritmo de la narración, de lectura y la impresión visual del texto, y cómo todo ello repercute en la posible interpretación de los pasajes. Orsini-Saillet (2007, 96-98) alude a ello en varios lugares de La larga marcha.

${ }^{19}$ La elocutio determina cómo han de expresarse verbalmente las ideas seleccionadas y estructuradas de la inventio y la dispositio; tiene en cuenta tres cualidades: puritas (corrección gramatical de la lengua empleada), perspicuitas (grado de comprensibilidad del discurso) y ornatus. Este último consta de dos formantes básicos: la elección de palabras (tropos y figuras) y su combinación (compositio). Su estudio resulta decisivo a la hora de clarificar las singularidades de los escritores de distintas épocas (una aproximación a todas estas cuestiones en la literatura española en Azaustre y Casas 1997).

${ }^{20} \mathrm{La}$ adición de «como le han prometido en la agencia» expresa un lamento parecido hacia la explotación económica del turismo. 
que aspiran a esa misma vida sin reparar en que las clases privilegiadas se siguen lucrando a costa de los asalariados y «buscan lugares más refinados para su veraneo» (Chirbes 2008, 144) ${ }^{21}$.

En los textos de Mediterráneos Chirbes suprimió otros pasajes -llamémosles de época o coyunturales- de los reportajes de Sobremesa, como la referencia a que la nueva estación de trenes de Lyon fue proyectada por Santiago Calatrava (Chirbes 2008, 64), tal vez para restarle importancia al premiado y mediático arquitecto, y a la novela de Álvaro Pombo, El metro de platino iriado (Chirbes 2008, 89), que recibió el Premio Nacional de la Crítica en 1990, pocos meses antes de la fecha de publicación del reportaje en abril de 1991.

La omisión de epítetos como «espléndido», «bellísimo», «impresionante», «imponente» (Chirbes 2008, 79-80), que no aportan matices conceptuales de importancia, redunda en la precisión lingüística de Chirbes, muy dado a eliminar elementos superfluos, estereotipados y carentes de significado («tejidos que llegaban», Chirbes 2008, 77, por «tejidos que, a través de los interminables desiertos y de los remotos océanos, llegaban»), y denota su voluntad de no ser excesivamente sentimental ni sensiblero. La supresión de otros adjetivos resulta bastante significativa y permite que el autor juzgue ciertas cuestiones, de manera que los bouchons de Lyon no son «estupendos» ni «animados» restaurantes, sino simplemente «populares» (Chirbes 2008, 71). Téngase en cuenta, no obstante, que Chirbes quizá hubiese prescindido de parte de los fragmentos anteriores u de otros similares en los reportajes de Sobremesa de no haber tenido que ajustarse a la plana de la revista.

Otras omisiones denotan el interés del escritor por reducir alusiones que tal vez consideró pedantes o elitistas. En los textos de Mediterráneos, Chirbes optó por la grafía española de términos extranjeros («Coliseo», Chirbes 2008, 159) y por suprimir secuencias del tipo «de cámara, un trío, un cuarteto, un soprano que canta un lied de Schubert», y escribir de forma mucho más llana «de cámara» (Chirbes 2008, 25). En varios casos, Chirbes introdujo en los textos de Mediterráneos apuntes eruditos, que aportan matices al texto, y adjetivos valorativos, que refuerzan el tono vivencial e íntimo. Así, Lyon es, como la había descrito Balzac en la novela Therèse Raquin, «calculadora y estricta» (Chirbes

${ }^{21}$ En el prólogo de Pecados originales, edición conjunta de las novelas La buena letra y Los disparos del cazador, Chirbes (2013, 7-8) indicó: «Los nuevos mecánicos de los engranajes del Estado [español a finales de los ochenta y comienzos de los noventa del siglo $\mathrm{XX}$ ] se aplicaban en la estrategia que Walter Benjamin define como propia de la socialdemocracia: señalaron con el dedo un futuro prometedor para que se olvidase la sangre derramada en el pasado: la injusticia original que, medio siglo antes, les había arrebatado la legitimidad a quienes la ostentaban. El pacto que se les propuso a los españoles, bajo el razonable argumento de cambiar pasado por futuro, fue un cambio de ideología por bienestar; es decir, un trueque de verdad por dinero. Y el país lo aceptó». 
2008, 71), y las fachadas de piedra de los edificios de la ciudad son «elegantes», pero también «tristes» (Chirbes 2008, 67) 22 .

Asimismo, expresiones como «verde pistacho»y «rojo Salmón», que podrían parecer prototípicas, adquieren un valor connotativo, puesto que sirven a Chirbes para lamentar «los densos colores» de los andamios que recubrían las fachadas de las iglesias y palacios romanos durante su estancia en la ciudad. Estas secuencias expresan a su vez el desacuerdo del autor con el modo en que se conservan o restauran algunos de esos edificios y objetos de arte, que pueden hacer «desaparecer [...] ese aura que dice Walter Benjamin que es característica de las obras de arte originales» al bruñir los materiales, reconstruir ciertos aspectos o alterar los colores («El tiempo de los dioses», Chirbes 2008, 155 156). Esta idea es fácilmente trasladable a lo que sucede con los discursos historicistas, que difuminan las aristas de las sociedades pasadas y presentes.

\subsection{Las variantes de «La puerta del Mar [Estambul]»y «La herencia del mundo [El Cairo]»}

A medio camino entre los leves casos de «autorreescritura» previos y los de mayor envergadura, que se examinan en páginas posteriores, se sitúan los reportajes que Chirbes (2008, 39-59 y 123-134) escribió sobre Estambul y El Cairo. Ambos comparten la distancia cultural que supone enfrentarse a dos civilizaciones de origen asiático; en el caso de Estambul se suma, además, una razón cronológica: «Estambul» fue publicado en el número de octubre de 1986 de la revista Sobremesa y la revisión, «La puerta del mar [Estambul]», se efectuó para la edición de Mediterráneos, editada en septiembre de 1997. Al igual que en casos anteriores, al reescribir estos textos Chirbes optó por una mayor precisión terminológica e introdujo matices conceptuales mediante el cambio, la adición y la supresión de determinadas secuencias:

Tít La puerta del mar $M$ : Estambul $S$

1-5 A las cinco... caminantes $M:$ om $S^{23}$

28-29 balanceantes $M$ : temblorosas $S$

${ }^{22}$ Las referencias eruditas de tipo literario delatan, muy probablemente, la diferencia que Chirbes establecía entre un espectáculo, como el del concierto de cámara al que se aludía líneas atrás, para el que se debe pagar una entrada y al que se puede asistir por motivos sociales y no por verdadero interés en la actuación, y la lectura o la literatura, un ejercicio solitario y que requiere de una inclinación real.

${ }^{23}$ El texto se vuelve a repetir en las líneas $18-22$ de $M$, con la modificación de «caminantes»; en la línea 23 se añade: «chicharritos, rodaballos, rubios». Chirbes estaría evocando así «La cogida y la muerte», primera parte del «Llanto por Ignacio Sánchez Mejías» de Federico García Lorca: los peces, al igual que el torero, son capturados y mueren «a las cinco de la tarde». 
29-30 madera, como parecía también milagroso que no se incendiaran $M$ : madera; como parecía también milagro que no ardiesen $S$

31-32 en las cubiertas de todas las embarcaciones $M$ : sobre todos ellos se levantaban $S$

33 Crepitaba $M$ : Crujía $S$

39 marineros $M$ : hombres $S$

40 y por gestos $M:$ om $S$

49-50 a juzgar por el trato $M:$ om $S$

337 Viena. $M$ : Viena. Occidente había perdido el norte $S$

Tit La herencia del mundo $M$ : Mercados de El Cairo. La herencia del mundo $S$

Lad. I $M$ : om $S$

3-4 ciudadela que Saladino mandó construir $M$ : altiva ciudadela de Saladino $S$

8 edificios públicos $M$ : edificios $S$

32 se pregunta $M$ : se interroga $S$

36 ilimitado. $M$ : ilimitado, la necesidad de vivir el momento. $S$

45 camino y que, como $M$ : camino, y que, como $S$

49 mansas y silenciosas aguas del Nilo $M$ : mansas aguas del Nilo silencioso $S$

50 poco rato después $M$ : poco después $S$

75-77 cuyo ambiente trasladaba el pensamiento del viajero a otros lugares queridos: las puertas de la mezquita $M$ : trasladaba al viajero junto a la mezquita $S$

97 los mitos del amor, la vida y la muerte $M: \operatorname{los}$ viejos mitos de la vida, el amor y la muerte $S$

106 ya -antes de que naciera- la tradición $M$ : ya cuando nació la tradición $S$ 107-108 el tiempo. El Cairo continuó el destino de la punta $M$ : el tiempo y la existencia. La orgullosa ciudad fatimita, El Cairo de los mamelucos recogió esa tradición de la punta $S$

131-132 ciudad: las mezquitas $M$ : ciudad. Las mezquitas $S$

Ejemplos de cambio serían los de «marineros» por «hombres» o «crepitaba» por «crujía»; de adición, los de «a juzgar por el trato», «y por gestos» o el de «edificios públicos» por «edificios»; de supresión, la eliminación de «Occidente había perdido el norte» o «la necesidad de vivir el momento».

Estas transformaciones varían la puntuación y dinamizan el ritmo lingüístico o de lectura («mansas y silenciosas aguas del Nilo» en lugar de «mansas aguas del Nilo silencioso», «los mitos del amor, la vida y la muerte» en lugar de «los viejos mitos de la vida, el amor y la muerte», etc.), pero, a diferencia de los textos que hacían mención a ciudades europeas (Creta, Lyon, Venecia, Benidorm, Roma), la reescritura en Mediterráneos de los textos dedicados a Estambul y El Cairo, es más frecuente y afecta a fragmentos más extensos:

Tít La puerta del mar $M$ : Estambul $S$

218-222 Mesopotamia, en la que peleaban (y siguen peleando) oriente y occidente; miraba hacia la nariz helada de Asia, hacia sus inmen- 
sas praderas y sus cumbres nocturnas y desconocidas en las que se acurrucaban hombres de los que $M$ : Mesopotamia -ayer y hoy ensangrentada- en la que le peleaban -y siguen peleando- oriente y occidente; en la nariz helada de Asia, de sus inmensas praderas y cumbres nocturnas y desconocidas en las que se acurrucaban hombres a quienes $S$

527-534 jamás; y que, además, pueblan Estambul los judíos irredentos, los griegos denostados, los franceses que han perdido el rumbo y ni siquiera saben si quieren encontrarlo de nuevo, los asesores militares, los turistas, los soldados de permiso o los campesinos que hacen cola ante una ventanilla con el dinero justo para pagar un pasaje a Berlín. $M$ : jamás, judíos irredentos, griegos denostados, europeos que han perdido el rumbo y ni siquiera saben si quieren encontrarlo, asesores militares, turistas, soldados de permiso y campesinos que hacen cola ante una ventanilla con el dinero justo para un pasaje a Berlín. $S$

Tit La herencia del mundo $M$ : Mercados de El Cairo. La herencia del mundo $S$

36-42 envolvía los edificios un aura de arena que filtraba la luz del sol, y el viajero, que apenas iba a poder asomarse a El Cairo en un corto viaje de trabajo, se preguntaba cuándo podría volver a la ciudad que, sólo entrevista, ya lo cautivaba. Ese polvo como un aura reluciente flotaba en torno a la imponente fábrica $M$ : que envolvía un aura de arena que filtraba la luz del sol, el viajero se preguntó cuándo podría volver a El Cairo. Ese polvo como un aura, que no era cursi, porque la grandeza del paisaje se lo impedía, flotaba en torno a la soberbia fábrica $S$

193-196 El Cairo no es una fijación arqueológica. Es una ciudad convulsa, desordenada, y un gran almacén en el que se recoge la espléndida cosecha del Nilo: productos $M$ : Pero El Cairo no se conforma exigiendo del viajero el trazado de esos círculos de larga distancia en el tiempo y en el espacio, ni es solo una fijación arqueológica. Es también el desmesurado almacén en el que se condensa la espléndida e interminable cosecha del Nilo, ese deslumbrante bodegón vegetal que crece tres veces al año: productos $S$

245-250 vegetal, y aturden los perfumes de las naranjas y granadas, o de los manojos de menta y coriandro, a los que se mezcla el olor de los excrementos y sudor de las bestias fatigadas por largos recorridos y también el del humo que desprende la grasa de cordero al quemarse en los carbones encendidos de las cocinillas. $M$ : vegetal, y la vitalidad de los cargadores y descargadores, y la fuerza de los aromas complejos, y la fuerza de los aromas complejos, el perfume de las naranjas, de las granadas, de la menta, del coriandro, el de los excrementos y el sudor de las bestias, el de la grasa que se asa en el carbón de las cocinillas. $S$

La revisión del texto sobre Estambul refuerza a su vez uno de los aspectos que ya se desprendía de los reportajes de Sobremesa dedicados a destinos que se consideran exóticos desde una perspectiva europea: la de no proyectar los 
prejuicios éticos y morales impuestos por la supremacía occidental, tal como había puesto de manifiesto Eduard Said en Orientalism (1978). En el texto de Mediterráneos sobre Estambul (Chirbes 2008, 44), el autor omitió el aspecto «bajito y ancho» del vendedor callejero que se dirigió a él y al fotógrafo que lo acompañó durante el viaje. Además de poco significativa, Chirbes debió de considerar la caracterización del vendedor como ofensiva hacia las personas que ejercen este tipo de labor y, quizá también, hacia los propios turcos. Por razones muy semejantes, Chirbes eliminaría expresiones como «exaltados judíos», «dioses tradicionales» o «fieles musulmanes», susceptibles de transmitir mayores prejuicios culturales e ideológicos que «bajito y ancho»:

Tít La puerta del mar $M$ : Estambul $S$

94 om $M$ : El caballero era bajito y ancho. $S$ el viajero $M:$ los viajeros $S$

104 El caballero demostró $M$ : El caballero bajito y ancho parecía [...] turco. Demostró $S$

199 del Imperio los dioses $M$ : del imperio, los dioses tradicionales $S$

170-171 el gozo del ayuno y la abstinencia de placeres sensuales. En su locura, llegaban a exaltar el dolor. Además, habían exigido la supresión $M$ : el ayuno, la abstinencia de placeres, e, incluso, el dolor. Los exaltados judíos habían llegado a exigir la supresión $S$

463 fieles $M$ : fieles musulmanes $S$

Precisamente, el uso del adjetivo denota el interés que Chirbes puso en la «autorreescritura» de los reportajes sobre Estambul y El Cairo, muy respetuosa con las sensibilidades culturales, y cuyo proceder contrasta con el de otros textos de Mediterráneos. Así, si en el texto referido a la ciudad de Génova se eliminaban adjetivos superfluos como «espléndido», «bellísima», «impresionante» e «imponente», en los que versan sobre Estambul y El Cairo se mantienen o añaden este tipo de calificativos para ponderar la grandeza de las ciudades («espléndidos edificios de Sinán», «dulces riberas», «esplendor»), o se prefieren ciertos adjetivos para evitar prejuicios etnocéntricos (Chirbes 2008, 53 , utiliza «comerciantes cristianos» y no «comerciantes occidentales») ${ }^{24}$ :

Tít La puerta del mar $M$ : Estambul $S$

353-354 musulmana -la de los espléndidos edificios de Sinán- y la $M$ : musulmana; la $S$

355 comerciantes cristianos $M$ : comerciantes occidentales $S$

${ }^{24}$ En sus novelas, Chirbes reiteró su empatía con aquellos colectivos más vulnerables social y económicamente, y en especial con los emigrantes. Otros detalles al respecto en Martínez Rubio (2016, 162-167), quien resalta: «en mi opinión, la enumeración "exótica" de Chirbes no responde tanto a una cosificación estándar de la realidad observada como a un verdadero interés por la representación de la gastronomía egipcia para la revista Sobremesa y de la cultura». 
524-525 las de las dulces riberas del Asia Menor, las del $M:$ de las dulces costas del Asia Menor, del $S$

Tit La herencia del mundo $M$ : Mercados de El Cairo. La herencia del mundo $S$

92 todo su esplendor $M$ : toda su belleza $S$

112-113 las del Nilo $M$ : las del misterioso Nilo $S$

124 -sigue siendo el más brillante-, una de las fabulosas $M:-$ lo sigue siendo-, era una de esas fabulosas $S$

193-196 El Cairo no es una fijación arqueológica. Es una ciudad convulsa, desordenada, y un gran almacén en el que se recoge la espléndida cosecha del Nilo: productos $M$ : Pero El Cairo no se conforma exigiendo del viajero el trazado de esos círculos de larga distancia en el tiempo y en el espacio, ni es solo una fijación arqueológica. Es también el desmesurado almacén en el que se condensa la espléndida e interminable cosecha del Nilo, ese deslumbrante bodegón vegetal que crece tres veces al año: productos $S$

237-238 soberbio, una verdadera explosión de vida. Mucho $M$ : soberbio. Mucho $S$

\subsection{Cambios sustanciales en el ritmo y el tono de Mediterráneos: «Añoranza de alguna parte [Valencia]» y «Arqueología del humo [Alejandría] $\gg^{25}$}

«Añoranza de alguna parte» y «Arqueología del humo» son los dos textos, de los diez cotejados de Mediterráneos, que mayores variantes presentan con respecto a los reportajes de Sobremesa. En «Añoranza de alguna parte», Chirbes eliminó los tres primeros párrafos y los ocho finales, en total unas doscientas ocho líneas en las que el escritor abundaba en sus recuerdos del Mercado Central de Valencia; en la visión que ofrecieron Blasco Ibáñez, en Arroz y tartana, y María Angeles Arazo, en Mercado Central de Valencia: 60 Aniversario; en los cambios urbanísticos sufridos por la ciudad de Valencia desde el siglo XVIII; y en los vendedores que pululaban por el mercado:

Cada vez que el viajero visita el Mercado Central de Valencia, se ve contagiado por esa gozosa sensación que provoca el espectáculo de la vida [...] La belleza del edificio, con sus cúpulas metálicas dejando que la luz bañe el interior [...]. Luego vino la decadencia de la ciudad que culminaría con el decreto borbónico de Nueva Planta [...] Los burgueses esnobs y recién instalados en el nuevo ensanche quisieron alejar a sus esposas del contacto popular [...] En Valencia, los vendedores, asociados o tomando sus decisiones [...] (Chirbes 1996, 26, 34 y 36).

Chirbes encontraría las observaciones sobre el mercado valenciano, con las que abría y cerraba el cuerpo del texto de la revista Sobremesa, demasiado

${ }^{25}$ Chirbes (2008, 31-38 y 93-102). 
ligadas al asunto del reportaje, titulado el «Mercado Central. El pulso de Valencia». Al reescribirlo como «Añoranza de alguna parte», el autor, que vivió la mayor parte de su vida lejos de la provincia de Valencia en la que nació, otorgó mayor importancia a los recuerdos de su niñez y dejó entrever, tal vez, la nostalgia que le produjo la temprana marcha de su tierra natal y la itinerancia de su vida ${ }^{26}$. El comienzo del texto de Mediterráneos, que lima las primeras sesenta y ocho líneas del de Sobremesa, ilustra estos aspectos:

Tít Añoranza de alguna parte $M$ : Mercado central. El pulso de Valencia $S$

1-3 Conocí el Mercado Central de Valencia cuando era un niño, cogido alternativamente de las manos de mi abuela, de mis tías abuelas y de mi madre. $M$

Cada vez que el viajero visita el Mercado Central de Valencia, se ve contagiado por esa gozosa sensación que provoca el espectáculo de la vida [...] Así que, al viajero, aquí se le mezclan irremediablemente el gozo y la nostalgia.

Porque el viajero conoció el Mercado Central de Valencia cuando era un niño, cogido alternativamente de las manos de su abuela, de sus tías y de su madre. $S^{27}$

El título de «Arqueología del humo» (Chirbes 2008, 93-102), que refundió el texto de Sobremesa «Alejandría. Un hermoso destello», revela el alcance de la «autoreescritura». Al igual que en «Añoranza de alguna parte», Chirbes prescindió de los elementos coyunturales, ligados a las circunstancias del reportaje (la llegada al «hotel», la habitación de «hotel»), y potenció el lirismo que le provocó la contemplación de la ciudad. Chirbes refinó de paso la redacción para dotar al texto de Mediterráneos de elementos más sutiles y evocadores que los del reportaje de Sobremesa («Una brisa yodada envolvía las mesas cubiertas con manteles de hule y abría los pulmones. Hasta los comensales llegaban las gotas de espuma de las olas que golpeaban unas rocas que se iban volviendo de cobre a medida que avanzaba el día [...] De cara al mar volví a recuperar la palabra Alejandría -el fulgor de un nombre--», Chirbes 2008, 96-

${ }^{26}$ Chirbes nació el 27 de junio de 1949 en Tavernes de la Valldigna (Valencia). En 1957 ingresó en un colegio de huérfanos para hijos de ferroviarios en Ávila, de allí pasó a otros en León y Salamanca; después cursaría en Madrid el Preuniversitario y la licenciatura en historia, y ya no volvería a establecerse en la provincia de Valencia hasta el año 2001 aproximadamente (véase Val 2015). Valls (2015) apunta: «El radical cambio de paisaje y de clima, el frío seco de Ávila y el húmedo de León, y la separación de su familia, le resultó en parte trágico pero también excitante».

${ }^{27}$ El texto de Sobremesa, del que se omite un extenso fragmento, se extiende por sesenta y ocho líneas: de la 1 a la 68. 
97 ${ }^{28}$. Por ello, en el texto de Mediterráneos sobre Alejandría abundan los párrafos en los que todas las oraciones han sido retocadas con respecto a la versión primigenia de Sobremesa:

Tit Arqueología del humo $M$ : Alejandría. Un hermoso destello $S$

Lad I $M$ : om $S$

1-12 El mar estaba allí, a mis pies, oculto por la noche y por los altos edificios en los que todavía brillaban luces en algunas ventanas. No llegaba hasta la habitación del hotel ningún rumor de oleaje, no sólo porque había muchos metros en la vertical del balcón hasta el agua, sino también porque una calma densa mantenía inmóvil la masa acuática. Reinaba la calma bajo una pesada cúpula de nubes. Llegaba, eso sí, un $M$

Al viajero le dio por preguntarse acerca de lo que, pasados los años, acabaría recordando de Alejandría. Fue así. Se metió en el hotel situado junto a la Corniche, miró el mar desde la ventana de la habitación, e intentó repasar cuanto había visto de la ciudad ¿Qué acabaría recordando de ella? El Mediterráneo estaba allí, oculto por la noche y por los edificios en los que brillaba todavía la luz de algunas ventanas. No llegaba ningún rumor de oleaje, porque una calma densa mantenía inmóvil la masa acuática. Calma bajo las nubes. Llegaba, eso sí, un $S$

37-70 La primera tarde había paseado por la barriada de Aboukir, en una zona que me anunciaron como de gran interés para el turista y que era como un paisaje en el que acabara de librarse alguna feroz batalla, un decorado de escombros y vigas y ladrillos y polvo, que, de repente, se apartó como un telón para mostrar la calma de un merendero blanco y azul. En aquel modesto local, en el que se exponían peces y crustáceos que formaban un magnífico bodegón, se metía toda la luz del mar en irisaciones de sol poniente. Una brisa yodada envolvía las mesas cubiertas con manteles de hule y abría los pulmones. Hasta los comensales llegaban las gotas de espuma de las olas que golpeaban unas rocas que se iban volviendo de cobre a medida que avanzaba el día. Al pie de la terraza del merendero había niños que perseguían cangrejos entre las piedras y pescadores que lanzaban el sedal y luego se quedaban inmóviles.

De cara al mar volví a recuperar la palabra Alejandría -el fulgor de un nombre- que se me apareció como una construcción de la mente sobre la constancia del aire y del agua y de la luz mediterráneas, una construcción sutil e imaginaria que apenas necesitaría de difusas huellas para levantarse: la columna de Pompeyo, las viejas necrópolis o las estatuas de miembros truncados que miran sin ojos

${ }^{28}$ Martínez Rubio $(2016,158-162)$ glosa el texto que Chirbes dedicó a Alejandría en Mediterráneos (Chirbes 2008, 93-102). 
en las galerías del Museo Grecorromano son el modesto pied à terre sobre el que el viajero puede seguir levantando ese particular edificio de la memoria, que es una sucesión en la historia y una concentración en la geografía, ambas enterradas bajo el asfalto de las recientes avenidas y los apartamentos construidos con materiales baratos; ambas sucedidas y prolongadas por asfalto y apartamentos que son una capa más sobre tanto derribo. $M$

La primera tarde, había paseado por Aboukir, en una zona que parecía el paisaje después de una batalla, un decorado de escombros y vigas y ladrillos y polvo, antes de llegar a la calma de un merendero blanco y azul en el que se recuperaba, de repente, todo el Mediterráneo en una irisación del sol poniente, en la espuma de unas rocas que se fueron volviendo de cobre y en las siluetas de los niños que jugaban y de los pescadores que lanzaban el hilo y luego se quedaban inmóviles de cara al mar.

En el hotel, muchas horas más tarde, lo pensó el viajero. Pensó en Alejandría -el fulgor de un nombre- como una construcción de la mente sobre la constancia del aire y la luz mediterránea, una construcción sutil e imaginaria que apenas necesita de difusas huellas para levantarse: la columna de Pompeyo, las viejas necrópolis o las estatuas de miembros truncados que miran sin ojos en las galerías del Museo Greco-Romano son el modesto «pied à terre» sobre el que el viajero puede seguir levantando ese edificio de la memoria que es una sucesión en la historia y una concentración en la geografía, ambas enterradas bajo el asfalto de las recientes avenidas y los apartamentos construidos con materiales baratos. $S$

En «Arqueología del humo» y «Añoranza de alguna parte», Chirbes ahondó, además, en los fenómenos de «autorreescritura» vistos páginas atrás (sustitución o supresión de secuencias que tienden a precisar la expresión, simplificar la sintaxis y agilizar el ritmo de lectura):

Tit Arqueología del humo $M$ : Alejandría. Un hermoso destello $S$

58 y de la luz mediterráneas $M:$ y la luz mediterránea $S$

59 necesitaría $M$ : necesita $S$

64-65 particular edificio $M$ : edificio $S$

65 memoria, que $M:$ memoria que $S$

68-70 ambas sucedidas y prolongadas por asfalto y apartamento que son una capa más sobre tanto derribo $M:$ om $S$

72 homérica queda $M:$ homérica, queda $S$

83 pescadores $M$ : marineros $S$

87-89 Del gran Alejandro -que le dio nombre-, de Antonio y Cleopatra, de sus naves de perfumadas maderas y lujosos tejidos, de César, $M$ : De Antonio y Cleopatra, de sus naves perfumadas maderas y sutiles tejidos de su amor, de César, $S$ 
90-95 disputas neoplatónicas que encendían los ánimos de los intelectuales de la ciudad, quedan algunas palabras en los libros y algunas piedras anónimas sumergidas en el malecón y cuyos perfiles ha borrado la acción del mar. Apenas nada. $M$ : disputas de neoplatónicos, quedan algunas piedras anónimas en el malecón, cuyos perfiles ha borrado la lengua del mar. Apenas nada. Un hilo tenue desde el que se teje el esplendoroso tapiz de riqueza y destrucción, de oro y fuego devastador restaurando periódicamente el dominio del inminente desierto y del tozudo mar $S$

Tit Añoranza de alguna parte $M$ : Mercado central. El pulso de Valencia $S$ 44 Un corazón moldeado $M$ : Un corazón formado $S$ 81-82 La dramática historia $M$ : la tragedia de $S$

Así pues, los textos de Mediterráneos, que sufrieron modificaciones más o menos profundas con respecto a los reportajes de la revista Sobremesa originarios, presentan variantes que delatan el detalle y el rigor con el que Chirbes revisaba sus textos. El autor apuró con ello todos los elementos textuales de significado, desde los aspectos visuales o formales (la presentación en bloques de texto o párrafos) hasta los más nimios: la supresión de una coma para cambiar un matiz explicativo por uno especificativo, el empleo de un paréntesis en lugar de un guión largo, la alternancia del pretérito imperfecto de subjuntivo por razones sonoras («levantara» $M$, Chirbes 2008, 53; «levantase» $\boldsymbol{S}$, Chirbes 1986). Chirbes también aprovechó para corregir erratas ortotipográficas, ciertos topónimos y errores gramaticales en el uso de la puntuación, de numerales y de artículos determinados e indeterminados.

\section{Recapitulación final: Chirbes y la «AUtorreescritura»}

El cotejo de las variantes entre los reportajes publicados en la revista $\mathrm{So}$ bremesa y los textos compilados en Mediterráneos permite intuir los procedimientos de «autorreescritura» de la obra de Chirbes y las sucesivas fases de elaboración de sus textos tanto periodísticos como de ficción. Las palabras de Herralde (2006, 84) adquieren así toda su dimensión: «Chirbes habla de las novelas en gestación como de un animal arisco, reacio a ser amaestrado. Pero al final la doma es perfecta, bruñida».

Además de los cambios derivados del cambio de formato, del paso de los textos de la revista Sobremesa al libro Mediterráneos («macrorreescritura»o «macroautorreescritura»), Chirbes depuró la expresión guiándose por los principios de claridad, economía lingüística y decoro. El escritor introdujo cambios en la sintaxis y la puntuación, que hacen más fluida la lectura y la comprensión, y omitió y sustituyó secuencias y voces, que trasladan matices más precisos y que ilustran sus convicciones de una forma más concreta. Chirbes evitó con 
ello parte de los datos y de los elementos coyunturales en los que redundaban los reportajes publicados en Sobremesa; ofreció una visión más íntima y personal y mucho más acorde con la de un novelista que con la de un periodista; y mostró el respeto y la sensibilidad que sentía por culturas y personas alejadas de la occidental, y los males del capitalismo, de la «mundialización» y del turismo desaforado. Chirbes, que ya había repudiado el sistema político y económico mundial en los reportajes de Sobremesa, continuó haciéndolo, con el mismo convencimiento y más argumentos a su favor por las prácticas especulativas y corruptas ulteriores, al reescribir cincuenta y cuatro de los reportajes de la revista en Mediterráneos y El viajero sedentario, y en todas sus novelas publicadas $^{29}$.

La escrupulosidad con la que Chirbes se tomó la «autorreescritura» de los reportajes de Sobremesa en Mediterráneos evidenció a su vez una gran exigencia consigo mismo y un gran respeto por el oficio de escritor y por la palabra impresa. Algunos textos sufrieron mayores transformaciones que otros, pero en todos se efectuó una revisión completa y generalizada; es decir, no se detectan, como a veces sucede en algunos autores por falta de interés o de tiempo, limas esporádicas, que suelen ser mayores en las líneas iniciales y finales, sino que Chirbes reescribió todo aquello que consideró oportuno a lo largo de todo el texto. De este modo, si la lengua o el estilo trasladan «une disposition de la existence, une manière d'être» (Morier 1985, 7) ${ }^{30}$, Chirbes mostró en la «autorreescritura» de los textos de Mediterráneos el tesón, la integridad, la sensibilidad y el compromiso que tuvo como periodista, ensayista, novelista y como individuo. Chirbes validó así sus propias palabras: «Escribir es trabajar en la organización del lenguaje de una determinada manera, y el lenguaje muestra irremediablemente las tensiones que la sociedad implanta en el autor [...] la novela delata a quien la escribe, se vuelve incluso contra él, lo denuncia» (Chirbes 2010, 15).

Asimismo, la «autorreescritura» efectuada por Chirbes de los textos de $\mathrm{Me}$ diterráneos abre la puerta al examen de otros que también pudieron ser reescritos; este análisis debería comenzar por los textos de Chirbes de carácter ensayístico recogidos en El novelista perplejo (Chirbes 2002) y Por cuenta propia (Chirbes 2010), que proceden de charlas, conferencias, prólogos a libros ajenos... En el

${ }^{29}$ Chirbes se avino, pues, a lo que Oleza $(1996,40)$ califica de «realismo posmoderno»: [un realismo] que ha perdido su universalidad, su arrogante centralismo, y que se sabe sujeto de diferencias, sujeto relativo, sujeto hombre o mujer, blanco o negro, del primer o del tercer mundo, del centro o de la periferia».

${ }^{30}$ El estilo es uno de los aspectos más destacados por los críticos en la obra de Chirbes; si bien, también subrayan que el virtuosismo expresivo se acompaña, en ocasiones, de sucesos y de personajes convencionales y estereotipados (Pozuelo 2010, 62-64). Para el estilo de Chirbes véanse los estudios de Morales Olivas (2006), Montero Curiel (2006), Winter (2006) o Llamas (2017). 
primero de ellos, el escritor justificó la compilación de forma parcialmente parecida a la antología de textos de Mediterráneos y El viajero sedentario, aunque no se explicita que las versiones primigenias haya sido retocadas: «A pesar de estar formado con materiales sedimentarios y acumulados durante una decena de años, creo que posee cierta unidad, aunque no sea más que la que le proporciona su carácter de periódico intento de abordar ese núcleo de duro de lo literario» (Chirbes 2002, 10). No obstante, el hecho de que los textos procedentes de la revista Sobremesa incorporados en Mediterráneos y El viajero sedentario hayan sido modificados, pese a que Chirbes no lo manifestase rotundamente en todos los casos, ofrece la posibilidad de rastrear «autorreescrituras» entre los textos de El novelista perplejo y Por cuenta propia y las versiones divulgadas anteriormente. Del mismo modo, la difusión de los cuadernos o diarios de Chirbes, en los que reunió materiales para sus novelas, aumentaría el conocimiento que se tiene de los mecanismos creativos del autor ${ }^{31}$ :

Cuando no estoy escribiendo ninguna novela, me hago la ilusión de que los cuadernos se convierten en pequeños depósitos que se van llenando con el combustible que la alimentará [...] Yo mismo relleno desde hace años cuadernos con ese propósito: cazar, capturar, ordenar las ideas para que tengan existencia, $\mathrm{y}$, como ya he dicho, almacenar materiales para mis libros (Chirbes 2009b, 15 y 20)

Por último, este artículo trata de reconocer la excelencia de la escritura de Chirbes; la virtud del hombre firme e independiente que fue, con la que el autor de este texto empatiza; y la clarividencia y contundencia de sus opiniones, que el autor de este texto aplaude:

En la literatura, me comporto como en la vida: tampoco en la vida he buscado hacerme amigo de los individuos que me han parecido más brillantes o capacitados para el éxito, sino de quienes me han parecido que cumplían ciertos rasgos

31 Sería interesante estudiar también la actividad periodística de Chirbes, resumida por Val (2014-2015, 287-305). Hasta ahora he intentado rastrear, sin éxito, el paso de Chirbes por El Ideal Gallego: «1981 [...] Se escapa en cuanto puede para caer en El Ideal Gallego. [...] Le prometen que el viejo periódico ultramontano ha cambiado de directrices, pero comprueba que es mentira [...] Tras el resultado de las elecciones generales de octubre [de] 1982, el director del Ideal, falangista reconocido, quiere llevar a portada, como tema principal, a Manuel Fraga, con la excusa de que, a pesar de haber sido arrasado por González, es el líder que más ha crecido en voto. Esa misma noche, Rafael Chirbes abandona La Coruña...» (Val 2014-2015, 288). En este sentido, resulta muy útil la recuperación en el número 0 de Universo Chirbes de textos de Chirbes como «Aquellos viejos hornos» (pp. 21-22) y «Pucheros, ollas, olletes y cocidos» (pp. 57-58), aparecidos en el Anuario de Cocina de la Comunitat Valencia; el de «Escribir la comida» (pp. 55-56), en Sobremesa, número 200; y el del texto escrito por Chirbes con motivo del nombramiento como hijo predilecto de Tavernes de la Valldigna (pp. 1516). Estos artículos, y otros inéditos o de más difícil acceso, deberían figurar en las futuras Obras completas del autor, porque aportan detalles muy significativos sobre su pensamiento y sobre los asuntos y el estilo de sus novelas. 
de afinidad; que encarnaban determinadas virtudes que yo necesitaba más que ese brillo seductor que puede cautivar a mucha gente (Chirbes 2002, 11).

Tengo solo una vida y hace años que elegí dedicarla a la literatura, y no al comercio (Chirbes 2010, 284).

\section{FUENTES}

Chirbes, Rafael. 1986. «Estambul». Sobremesa 30, octubre: 54-66.

Chirbes, Rafael. 1991a. En la lucha final. Barcelona: Anagrama.

Chirbes, Rafael. 1991b. «Venecia. El naufragio interior». Sobremesa 80, abril: 58-70.

Chirbes, Rafael. 1994a. «Alejandría. Un hermoso destello». Sobremesa 110, enero: 56-62.

Chirbes, Rafael. 1994b. «Mercados de El Cairo. La herencia del mundo». Sobremesa 114, mayo: 46-51.

Chirbes, Rafael. 1995. «Breve encuentro con Lyon. En el camino». Sobremesa 131, diciembre: $40-48$

Chirbes, Rafael. 1996a. «Benidorm en invierno. Desde el Estado del bienestar». Sobremesa 134, marzo: 14-25.

Chirbes, Rafael. 1996b. «Viaje a Creta. Fragmentos de la Edad de Oro». Sobremesa 138, julio-agosto: $58-68$.

Chirbes, Rafael. 1996c. «Mercado Central. El pulso de Valencia». Sobremesa 139, septiembre: $26-36$.

Chirbes, Rafael. 1996d. «La resaca de la historia. Génova». Sobremesa 142, diciembre: 6070.

Chirbes, Rafael. 1997a. Mediterráneos. Madrid: Debate.

Chirbes, Rafael. 1997b. «Volver a Roma. El tiempo de los dioses». Sobremesa 144, febrero: 56-63.

Chirbes, Rafael. 1997c. «El naufragio interior». Turia: revista cultural 41: 37-40.

Chirbes, Rafael. 2000. La buena letra. Madrid: Debate.

Chirbes, Rafael. 2002. El novelista perplejo. Barcelona: Anagrama.

Chirbes, Rafael. 2004. El viajero sedentario. Ciudades. Barcelona: Anagrama.

Chirbes, Rafael. 2008. Mediterráneos. Barcelona: Anagrama.

Chirbes, Rafael. 2009a. Rafael Chirbes en diálogo con Santos Alonso. Fundación Juan March, 5 de febrero de 2009. http://www.ieturolenses.org/revista_turia/index.php/ actualidad_turia/la-narrativa-de-rafael-chirbes-entre-las-sombras-de-la-historia Acceso el 10-11-2017.

Chirbes, Rafael. 2009b. «Textos ventaneros del 3 al 14 de julio de 2009». Diarios, Blog El Boomeran(g). http://www.elboomeran.com/upload/ficheros/noticias/diariochirbes.pdf Acceso el 12-11-2017.

Chirbes, Rafael. 2010. Por cuenta propia. Leer y escribir. Barcelona: Anagrama.

Chirbes Rafael. 2013. Pecados originales. La buena letra y Los disparos del cazador. Barcelona: Anagrama. 


\section{BIBLIOGRAFÍA CITADA}

Arcotxa-Scarcia, Aurelia, Javier Lluch-Prats y Mari Jose Olaziregi. 2010. En el taller del escritor. Génesis textual y edición de textos. Bilbao: Servicio Editorial de la Universidad del País Vasco.

Aron, Thomas. 1987. La réécriture du texte littéraire, Semen. Annales Littéraires de l'Université de Besançon, 3.

Azaustre, Antonio y Juan Casas. 1997. Manual de retórica española. Madrid: Akal.

Braudel, Fernand. 1966. La Méditerranée et le monde méditeranéen à l'époque de Philippe II. Paris: Armand Colin.

Fernández Martínez, Dolores. 2021. «Et in Arcadia Ego. El viaje a Creta de Rafael Chirbes». En El universo de Rafael Chirbes, ed. Javier Lluch-Prats, 293-306. Barcelona: Anagrama.

García Prats, Soledad. 2013. Memoria y ciudad en «Mediterráneos» (1997). Implicaciones simbólicas, topográficas y antropológicas de la escritura de viajes. Dissertation zur Erlangung des Doktorgrades der Philosophischen Fakultät der Christian- Albretchs. Universität zu Kiel.

Genette, Gerard. 1982. Palimpsestes: La littérature au second degré. Paris: Seuil.

Gómez Alonso, Juan Carlos. 2017. «Intertextualidad, interdiscursividad y retórica cultural». Tropelias 1: 107-105. https://doi.org/10.26754/ojs_tropelias/tropelias.201712104

Gómez López-Quiñones, Antonio. 2006. «Chirbes, Rafael. El viajero sedentario. Ciudades. Barcelona: Anagrama, 2004. 372 pp.». España contemporánea 19 (1): 108-110.

González Álvarez, Cristóbal. 2003. «La intertextualidad literaria como metodología didáctica de acercamiento a la literatura: aportaciones teóricas». Lenguaje y textos 21: 115-127.

Herralde, Jorge. 2006. Por orden alfabético. Escritores, editores, amigos. Barcelona: Anagrama.

Iglesias Feijoo, Luis. 2013. «La edición crítica de textos contemporáneos». En Perspectivas críticas para la edición de textos de literatura española, ed. Ermitas Pena, 161-190. Santiago de Compostela: USC Editora.

Llamas Martínez, Jacobo. 2017. «Una aproximación al ritmo lingüístico, el tono y la puntuación en las novelas de Rafael Chirbes». Tonos 32: 1-17.

Lledó, Emilio. 1992. El silencio de la escritura. Madrid: Espasa-Calpe.

López de Abiada, José Manuel. 2011. «Entrevista a Rafael Chirbes». En La constancia de un testigo. Ensayos sobre Rafael Chirbes, ed. Augusta López Bernasocchi y José Manuel López de Abiada, 12-20. Madrid: Verbum.

Luengo, Ana. 2009. «De cómo confluyen La caída de Madrid y La gallina ciega. Memorias incómodas de la otra España». Aletria 2 (19): 145-162.

Maggi, Eugenio. 2015. «Intertextualidad y estrategias traductoras. Sobre algunas versiones de un pasaje de En la orilla (Rafael Chirbes, 2013)». Creneida 3: 375-385.

Martínez Fernández, José Enrique. 2001. La intertextualidad literaria. Madrid: Cátedra.

Martínez Rubio, José. 2016. «Retratos del tiempo con pirámides al fondo. La visita de Rafael Chirbes a Egipto». En Tempus en Misr. Historia y porvenir del Hispanismo en Egipto, ed. María J. Rodrigo Mora, Ana Pano Alamán y Silvia Betti, 155-168. Bolonia: Emil.

Montero Curiel, Pilar. 2006. «La ambientación lingüística en "Mimoun”, de Rafael Chirbes». En Ensayos sobre Rafael Chirbes, ed. María Teresa Ibáñez Ehrlich, 135-157. Madrid Frankfurt am Main: Iberoamericana - Vervuert.

Mora, Miguel. 1997. «Chirbes reúne sus relatos de viajes mediterráneos, de Benidorm a Egipto». El País, 31 de octubre. 
Morales Olivas, Luis. 2006. «El elemento lírico en la narrativa de Rafael Chirbes». En Ensayos sobre Rafael Chirbes, ed. María Teresa Ibáñez Ehrlich, 159-174. Madrid Frankfurt am Main: Iberoamericana - Vervuert.

Morier, Henri. 1985. La psychologie des styles. Genève: Georg.

Oleza, Joan. 1996. «Un realismo postmoderno». Ínsula enero-febrero: 589-590.

Orsini-Salillet, Catherine. 2007. L'écriture fragmentaire de la memoire. Habilitation à diriger des recherches (tuteur Jacques Soubeyroux). Université Jean Monnet-Saint-Étienne.

Plett, Heinrich F. 1993. «Intertextualidades». Criterios julio: 65-94.

Pozuelo Yvancos, José María. 2010. 100 narradores españoles de hoy. Palencia: Menoscuarto.

Ricardou, Jean. 1989. «Pour une théorie de la récriture». Poétique: Revue de théorie et d'analyse littéraires 77: 3-15.

Rodríguez-Gallego, Fernando. 2016. «En el taller de Calderón: motivos y pasajes de una de sus comedias más tempranas, Judas Macabeo, que serán recurrentes en su obra posterior». Atalanta 4 (2): 87-136.

Sáez, Adrián J. 2013. «Reescritura e intertextualidad en Calderón: No hay cosa como callar». Criticón 117: 159-176.

Senabre, Ricardo. 2015. El lector desprevenido. Oviedo: Ediciones Nobel.

Val, Fernando del. 2014-2015. «Biocronología de Rafael Chirbes». Turia 112: 280-305.

Valls, Fernando. 2014-2015. «La narrativa de Rafael Chirbes: entre las sombras de la historia». Turia 112: 125-145.

Valls, Fernando. 2016. «Cabeza de ofidio, ojos de reptil: a propósito de Paris-Austerlitz, de Rafael Chirbes Fernando Valls». Caracol 11: 30-51.

Vauthier, Bénédicte y Jimena Gamba Corradine. 2012. Crítica genética y edición de manuscritos hispanos contemporáneos. Salamanca: Universidad.

Vitse, Marc. 1998. «Presentación». Criticón 72: 5-10.

Winter, Ulrich. 2006. «Adivinación hermenéutica, historia de las mentalidades y autenticidad. Acerca del estilo historiográfico de Rafael Chirbes». En Ensayos sobre Rafael Chirbes, ed. María Teresa Ibáñez Ehrlich, 235-247. Madrid - Frankfurt am Main: Iberoamericana - Vervuert.

Fecha de recepción: 27 de febrero de 2018.

Fecha de aceptación: 19 de abril de 2018. 